\title{
Rencana pengembangan kawasan wisata berbasis kearifan lokal pada area pasca tambang timah di Kecamatan Merawang Kabupaten Bangka
}

\author{
Tourism development plans based on local wisdom in tin post mining area in Merawang District, \\ Bangka Regency
}

Rifqi Adi Nugraha ${ }^{\mathrm{a}}$, Afra D. N. Makalew ${ }^{\mathrm{b}}$, Syartinilia $^{\mathrm{b}}$

\begin{abstract}
${ }^{a}$ Program Studi Arsitektur Lanskap, Sekolah Pascasarjana, Institut Pertanian Bogor, Kampus IPB Darmaga Bogor, 16680, Indonesia [+62 82183987624]

${ }^{\mathrm{b}}$ Departemen Arsitektur Lanskap, Fakultas Pertanian, Institut Pertanian Bogor, Kampus IPB Darmaga Bogor, 16680, Indonesia
\end{abstract}

\section{Article Info:}

Received: 09 - 03 - 2020

Accepted: $01-07$ - 2020

\section{Keywords:}

Conservation, land suitability, local wisdom, planning tourism, post mining

Corresponding Author: Rifqi Adi Nugraha Program Studi Arsitektur Lanskap, Sekolah Pascasarjana, Institut Pertanian Bogor; Tel. +6282183987624 Email:

rifqiadin30@gmail.com

\begin{abstract}
Abstrak. Environmental damage due to tin mining in Bangka Regency, especially in Merawang District is increasing. The negative impacts of this mining are eliminating the composition or structure of vegetation, changing the function of wildlife habitats, changing the shape of the landscape, producing waste, and draining ground and surface water. One form that can be developed in the development of post-tin mining areas that are environmentally friendly is the development of tourism based on local wisdom while still paying attention to natural resources, especially conservation areas such as protected forests and borders. Tourism development is carried out to restore the area with various activities that involve the community. The results of spatial analysis of tourism suitability in Merawang District have very suitable criteria (S1) with tourism suitability index (IKW) of $84.05 \%$ and conditional suitable (S3) with IKW value of $9.31 \%$ and not suitable $(N)$ with $I K W$ value of $6.66 \%$. Local wisdom in Merawang District is based on AHP analysis in the ecological aspects of "customary forests", social aspects of "nganggung", economic aspects of "typical culinary", and historical aspects of "becampak". Meanwhile, the most priority local wisdom based on all aspects is obtained "typical culinary".
\end{abstract}

How to cite (CSE Style $8^{\text {th }}$ Edition):

Nugraha RA, Makalew ADN, Syartinilia. 2020. Rencana pengembangan kawasan wisata berbasis kearifan lokal pada area pasca tambang timah di Kecamatan Merawang Kabupaten Bangka. JPSL 10(3): 374-389. http://dx.doi.org/10.29244/jps1.10.3.374-389

\section{PENDAHULUAN}

Kabupaten Bangka merupakan salah satu penghasil timah terbesar di Pulau Bangka. Berdasarkan data Badan Pusat Statistik Kabupaten Bangka tahun 2019 jumlah produksi bijih timah di Kabupaten Bangka sebesar 4723.47 ton dan logam timah sebesar 7196.61 ton. Menurut Laporan Keberlanjutan PT. Timah Tbk Tahun 2018 Izin Usaha Pertambangan (IUP) di Kabupaten Bangka terdapat di darat, laut dan kawasan hutan produksi dengan luas masing-masing yaitu 62068.01 ha di darat, 19756 ha di laut dan 19470.87 ha di kawasan hutan produksi. Keberadaan sektor pertambangan memberikan dampak positif dan dampak negatif. Dampak positif yang diperoleh yaitu peningkatan ekonomi dan penyerapan tenaga kerja. Dampak negatif dari pertambangan timah yaitu merusak dan menghilangkan komposisi dan struktur vegetasi, menghilangkan atau merubah fungsi habitat satwa liar, mengubah bentuk bentang alam, menghasilkan limbah, serta menguras air tanah dan air 
permukaan. Apabila lahan bekas pertambangan timah tidak direhabilitasi, lahan-lahan tersebut akan membentuk lubang yang disebut kolong serta menghasilkan tanah yang bersifat masam.

Dalam RTRW Kabupaten Bangka Tahun 2010-2030 dijelaskan bahwa terdapat isu bidang ekonomi dan lingkungan hidup berupa akibat dari proses penambangan, hingga saat ini banyak terdapat lubang-lubang kecil maupun besar yang merupakan lubang bekas area penambangan, penggunaan lahan sebelumnya, terutama untuk kolong kolong yang terjadi akibat kegiatan TI (Tambang Inkonvensional). Kerusakan lahan dari aktivitas pertambangan timah semakin meningkat karena berkembangnya aktivitas tambang inkonvensional. Hal tersebut dapat diminimalisir dengan pengembangan pada kawasan pasca tambang yang tetap memerhatikan lingkungan serta dapat menyerap tenaga kerja masyarakat pasca tambang. Menurut Anwar et al. (2012) pengaturan dapat mengarahkan alokasi penggunaan lahan pasca tambang yang memberikan manfaat bagi masyarakat lokal, seperti menyediakan pekerjaan pasca tambang, reklamasi lahan dengan komoditas yang dapat memberdayakan masyarakat dan memberikan keuntungan serta menciptakan kembali tanah dalam keadaan semula.

Kecamatan Merawang merupakan salah satu kecamatan di Kabupaten Bangka yang termasuk dalam Wilayah Izin Usaha Pertambangan (WIUP) PT. Timah Tbk. Menurut Sari dan Buchori (2015), Kecamatan Merawang memiliki luas operasi produksi sebesar 880 ha. Lubang bekas tambang atau kolong merupakan gambaran dari kegiatan penambangan yang pernah dilakukan, tetapi pada lahan tersebut belum dilakukan kegiatan penimbunan kembali. Pembukaan lahan pertambangan yang tidak diiringi pengetahuan mengenai dampak yang akan ditimbulkan dapat merubah kondisi lingkungan di lokasi tambang dan sekitarnya. Salah satu bentuk yang dapat diupayakan dalam pengembangan kawasan pasca tambang timah berwawasan lingkungan yaitu pengembangan wisata berbasis kearifan lokal dengan tetap memerhatikan sumber daya alam yang ada di sekitar kawasan khususnya kawasan konservasi seperti hutan lindung dan sempadan. Menurut Chasanah et al. (2017), Pembangunan dan pengembangan sektor pariwisata dapat memberikan pengaruh positif, baik secara langsung maupun tidak langsung. Menurut Sangchumnong (2019), daya tarik pariwisata yang menyatu dengan alam dan sekitarnya serta terkait dengan masyarakat dapat menciptakan pengalaman yang menyenangkan, baru dan unik.

Menurut Ghazali et al. (2014), Kearifan lokal yang diterapkan telah terbukti pada beberapa daerah mampu menjaga keberlanjutan dan kelestarian sumber daya. Kearifan lokal pada suatu wilayah jika dipraktikan dengan benar dan bersungguh-sungguh akan menjadi norma, etika, dan moral yang dapat menuntun masyarakat untuk lebih peduli dan bertanggung jawab terhadap lingkungan. Menurut Chamidah et al. (2018), wisatawan tertarik untuk mengunjungi tempat-tempat khusus serta berinteraksi dengan berbagai kegiatan sehingga dapat memperkaya pengetahuan dan berpetualang serta mempelajari budaya setempat. Hal ini dapat dijadikan sebagai salah satu komponen dalam pengembangan kawasan wisata yang dapat dikolaborasikan dengan aspek berkelanjutan yaitu ekologi, sosial budaya, ekonomi dan sejarah. Penelitian ini bertujuan untuk mengetahui kesesuaian wisata dan pengembangan kearifan lokal prioritas dari aspek ekologi, sosial budaya, ekonomi dan sejarah pada area pasca tambang timah di Kecamatan Merawang sehingga dapat dilakukan pengembangan yang berkelanjutan dan selaras dengan kearifan lokal yang ada pada kawasan penelitian.

\section{METODE}

\section{Lokasi dan Waktu Penelitian}

Penelitian ini dilaksanakan pada bulan Juli sampai dengan Desember 2019 pada kawasan pasca tambang timah yang berada di Kecamatan Merawang dengan luas wilayah kurang lebih 21516.03 ha. Secara geografis kawasan ini terletak pada $106^{\circ} 7^{\prime} 44.08^{\prime \prime E}$ dan $1^{\circ} 59^{\prime} 0.41$ "S dengan batas administrasi yaitu, batas utara dengan Kecamatan Sungailiat, batas selatan dengan Kota Pangkalpinang, batas barat dengan Selat Gaspar, batas timur dengan Kecamatan Pemali dan Kecamatan Mendo Barat. Adapun untuk lebih jelasnya dapat dilihat pada Gambar 1. 


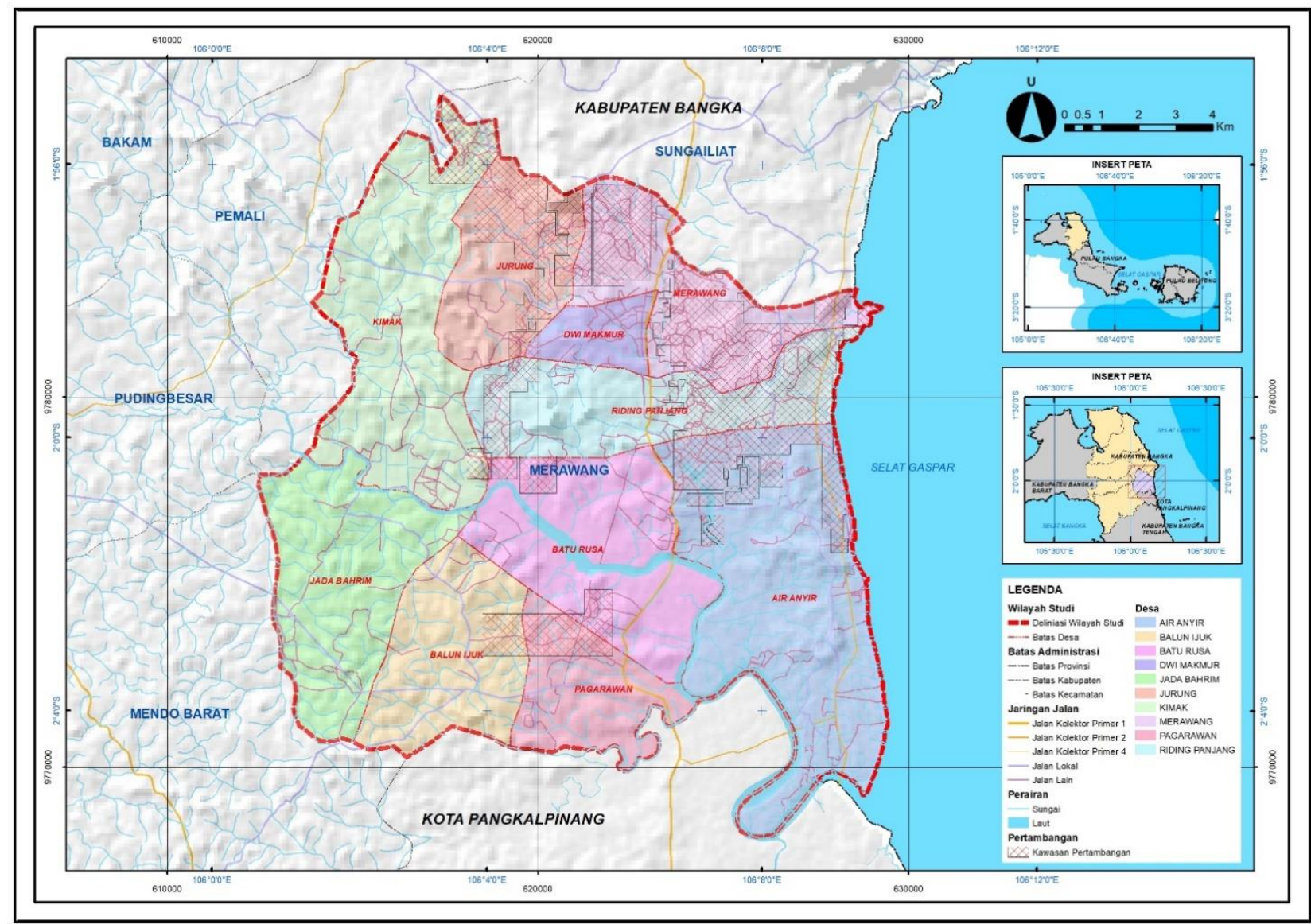

Gambar 1 Lokasi penelitian

\section{Metode Pengumpulan Data}

Metode yang akan digunakan dalam penelitian ini mengikuti proses perencanaan yang dikemukakan oleh Gold (1980) yaitu melaksanakan tahapan penelitian yang terdiri atas inventarisasi, analisis data, sintesis dan perencanaan. Metode pengumpulan data atau inventarisasi menggunakan metode deskriptif kuantitatif. Pengumpulan data primer dan data sekunder dilakukan dengan metode survei lapangan, kuesioner dan studi literatur. Data primer diperoleh melalui survei pengamatan langsung pada tapak dan wawancara dengan pihakpihak terkait, sedangkan data sekunder diperoleh melalui studi dari berbagai pustaka diantaranya Dinas Pariwisata, Kepemudaan dan Olahraga Kabupaten Bangka, Dinas Pendidikan dan Kebudayaan Kabupaten Bangka, dan Tokoh Masyarakat. Data terkait aspek fisik dan biofisik didapat berdasarkan studi pustaka dan dokumen-dokumen Dinas Pekerjaan Umum dan Perumahan Rakyat Kabupaten Bangka berupa peta-peta spasial, citra satelit spot 6 dan 7 tahun 2017 dengan resolusi 1.5 meter dan data DEMNAS (Digital Elevation Model Nasional) tahun 2018 dari Badan Informasi Geospasial serta survei lapang berupa kondisi lapang, wawancara dan kuesioner. Data terkait aspek sosial khususnya preferensi masyarakat dilakukan dengan penyebaran kuesioner dengan teknik purposive sampling atau pemilihan responden secara sengaja dengan pertimbangan responden adalah masyarakat yang tinggal di sekitar kawasan pengembangan dengan sampel pada aspek sosial sebanyak 30 responden. Sementara itu, untuk memperoleh data primer kearifan lokal yaitu wawancara dengan dinas dan stakeholder terkait sebanyak 3 responden diantaranya Dinas Pariwisata Kabupaten Bangka, Dinas Pendidikan dan Kebudayaan Kabupaten Bangka serta Tokoh Masyarakat yang dimana digunakan dalam AHP (Analysis Hierarchy Process). Sehingga pada penelitian ini sampel yang digunakan sebanyak 33 sampel. 


\section{Metode Analisis Data}

Metode analisis data yang digunakan yaitu metode analisis kesesuaian wisata dengan teknik overlay SIG (Sistem Informasi Geografis) dan metode AHP (Analisis Hirarki Proses) untuk analisis kearifan lokal yang ada pada wilayah studi. Kesesuaian untuk kegiatan wisata diadaptasi dari kriteria spasial menurut Kliskey (2000) dimana penilaian kesesuaian tersebut menggunakan pendekatan spasial yang juga merupakan analisis kuantitatif yang dilakukan terhadap beberapa faktor dari aspek fisik dan biofisik. Analisis spasial dilakukan dengan menggunakan teknik overlay SIG. Hasil dari tumpang tindih ini adalah peta tematik kesesuaian untuk kegiatan rekreasi pada kawasan wisata yang sesuai dengan kondisi lokasi yang komponen-komponen pentingnya menurut Kliskey (2000).

Selanjutnya dari komponen-komponen penting tersebut diklasifikasikan menjadi peubah kriteria spasial dari kesesuaian lahan untuk kegiatan rekreasi pada kawasan wisata. Klasifikasi tersebut dapat dilihat pada Tabel 1 yang kemudian selanjutnya dari tabel tersebut diturunkan menjadi kriteria spasial untuk kondisi kawasan aktual yang dapat diproses dengan SIG, dapat dilihat pada Tabel 2.

Tabel 1 Kriteria spasial kesesuaian lahan untuk kegiatan wisata

\begin{tabular}{cllc}
\hline No & \multicolumn{1}{c}{ Peubah } & \multicolumn{1}{c}{ Kriteria Spasial } & Pembobotan \\
\hline 1 & Keterbukaan (KT) & Kelas penutupan lahan & 4 \\
2 & Aksesibilitas (AS) & Jarak dari jalan utama & 3 \\
3 & Kemiringan (KM) & Kelas kemiringan & 2 \\
4 & Kondisi Vegetasi (KV) & Jenis Vegetasi & 2 \\
5 & Topografi (TP) & Elevasi & 1 \\
\hline
\end{tabular}

Sumber: Kliskey (2000) untuk kawasan wisata

Tabel 2 Kriteria spasial yang sesuai untuk kawasan wisata

\begin{tabular}{|c|c|c|c|c|c|}
\hline \multirow{2}{*}{ Kriteria } & \multirow{2}{*}{ Atribut (Unit) } & \multicolumn{4}{|c|}{ Kesesuaian Kawasan Wisata } \\
\hline & & 4 & 3 & 2 & 1 \\
\hline Keterbukaan & Penutupan lahan & Kebun & Hutan & Sawah & Lainnya \\
\hline Aksesibilitas & Jarak dari jalan utama $(\mathrm{km})$ & $0-5$ & $5-10$ & $10-15$ & $>15$ \\
\hline Kemiringan & Derajat kontur $\left(^{\circ}\right)$ & $0-20$ & $20-25$ & $25-30$ & $>30$ \\
\hline Vegetasi & Jenis Vegetasi & Pohon & Semak & Sawah & - \\
\hline Topografi & Elevasi & $0-500$ & $500-1000$ & $1000-1500$ & $>1500$ \\
\hline
\end{tabular}

Sumber: Modifikasi Kliskey (2000) untuk kawasan wisata

Hasil analisis kesesuaian wisata berupa nilai IKW (Indeks Kesesuaian Wisata) antara 0.0 (tidak sesuai untuk kegiatan wisata) sampai dengan 1.0 (sangat sesuai untuk kegiatan rekreasi) serta dikelompokkan ke dalam empat kelas interval kesesuaian diantaranya Tinggi (sangat sesuai): 0.76-1.0, Sedang (sesuai): 0.510.75, Rendah (sesuai bersyarat): $0.26-0.50$, Nol (tidak sesuai): 0.00-0.25. Selanjutnya nilai IKW dirumuskan pada persamaan berikut:

$$
\mathrm{IKW}=(4 \mathrm{SRKT}+3 \mathrm{SRAS}+2 \mathrm{SRKM}+2 \mathrm{SRKV}+1 \mathrm{SRTP}) / 12
$$

Keterangan:

SRKT = Sesuai rekreasi dari aspek keterbukaan

SRAS = Sesuai rekreasi dari aspek aksesibilitas

SRKM = Sesuai rekreasi dari aspek kemiringan

SRKV = Sesuai rekreasi dari aspek kondisi vegetasi

SRTP = Sesuai rekreasi dari aspek topografi 
Selanjutnya hasil dari analisis IKW ini kemudian di overlay kembali dengan peta kawasan hutan lindung dan sempadan. Kawasan hutan lindung dan sempadan dalam kebijakan pemerintah disebut sebagai kawasan penyangga pada area pengembangan serta pada kawasan ini juga merupakan kawasan dengan pengembangan bersyarat sebagai kawasan komersial karena dapat mengganggu ekosistem yang ada pada kawasan.

Pada Analisis kearifan local, metode yang digunakan dalam analisis ini yaitu Metode AHP (Analysis Hierarchy Process) merupakan suatu model yang diperkenalkan oleh Thomas L. Saaty pada tahun 1971. AHP adalah salah satu metode dalam sistem pengambilan keputusan yang menggunakan beberapa variabel dengan proses analisis bertingkat. Analisis dilakukan dengan memberi nilai prioritas dari tiap-tiap variabel, kemudian melakukan perbandiangan berpasangan dari variabel-variabel dan alternatif-alternatif yang ada. Metode ini digunakan untuk membangun suatu model dari gagasan dan membuat asumsi untuk mendefinisikan persoalan dan memperoleh pemecahan yang diinginkan, serta memungkinkan menguji kepekaan hasilnya (Saaty, 1990).

Sampel yang digunakan adalah purposive sampling, yaitu mereka yang dianggap mengerti. Analisis hierarki proses dalam kearifan lokal digunakan untuk melihat tingkat kepentingan kearifan lokal yang digunakan dalam pengembangan berdasarkan sudut pandang para ahli. Peniliaian ini dilakukan menggunakan software expert choice. Pada penelitian ini responden terdiri dari dinas pariwisata, dinas kebudayaan dan tokoh masyarakat. Penerapan AHP pada penelitian ini dilakukan dengan cara mencari semua kearifan lokal yang ada di lokasi penelitian terkait rencana pengembangan, kemudian mengurutkannya untuk mengetahui kearifan lokal mana yang paling prioritas untuk masyarakat dengan harapan nantinya akan didapat suatu rencana pengembangan kawasan wisata berbasis kearifan lokal pada kawasan pasca tambang. Tahap penilaian kearifan lokal ini dilakukan dengan cara menilai aspek yang paling penting untuk dikembangkan. Kemudian menilai kearifan lokal mana yang paling penting berdasarkan masing-masing aspek dan penilaian kombinasi secara keseluruhan aspek dan responden. Pada penilaian ini dilihat juga Inconsistensy Ratio (IR) yaitu nilai yang dapat menjadi acuan sebagai pengembangan apabila nilai IR $<10 \%$ atau 0.1 .

Menurut Ghazali et al. (2014) Kearifan lokal yang didapat akan dicari yang paling prioritas dengan berdasarkan pada pertimbangan tiga aspek, yaitu aspek ekologi berhubungan dengan ketersediaan sumber daya dan konservasi lingkungan dalam perencanaan kawasan wisata yang digunakan dalam kearifan lokal yang dimaksud, aspek ekonomi berhubungan dengan besarnya nilai pendapatan yang diterima oleh masyarakat yang melakukan kearifan lokal yang dimaksud dalam pengembangan wisata, serta cakupan pangsa pasarnya, aspek sosial berhubungan dengan besarnya jumlah tenaga kerja yang mampu diserap dari melakukan kearifan lokal yang dimaksud dalam pengembangan wisata serta prospek keberlanjutan dari usaha tersebut. Sementara itu pada penelitian ini ketiga aspek tersebut digunakan kemudian ditambah satu aspek lagi yaitu aspek sejarah yang berhubungan dengan sejarah adanya kearifan lokal pada lanskap tropis khususnya di Kecamatan Merawang.

\section{HASIL DAN PEMBAHASAN}

\section{Kondisi Biofisik}

Faktor biofisik mempertimbangkan pengembangan suatu lanskap dengan melihat kondisi sumber daya alam sekitar. Kualitas faktor biofisik dapat dikatakan baik jika interaksi antara komponen biotik dan abiotik saling berhubungan dan saling mempengaruhi satu sama lain dengan seimbang. Dalam pengembangan ini, dapat dilihat kawasan yang sesuai atau tidak sesuai untuk dikembangkan dalam pengembangan kawasan wisata dengan tetap memerhatikan kawasan lindung maupun kawasan konservasi lainnya yang berada pada kawasan sehingga konsep pembangunan berkelanjutan dapat dilaksanakan. Menurut Syartinilia et al. (2019) dalam jurnalnya menyebutkan bahwa konservasi merupakan salah satu dan peluang untuk membangun strategi pembangunan yang berkelanjutan dengan tujuan untuk menyeimbangkan antara pengembangan lahan, perlindungan lingkungan dan kesejahteraan masyarakat. Faktor biofisik yang memengaruhi pengembangan pada penelitian ini meliputi penutupan lahan, aksesibilitas, kemiringan, vegetasi, topografi dan kawasan konservasi seperti kawasan hutan dan sempadan. 


\section{Penutupan Lahan}

Penutupan lahan merupakan pemanfaatan lahan di suatu wilayah. Kondisi penutupan lahan di Kecamatan Merawang meliputi permukiman, rawa, kolong, empang, sungai, hutan rimba, perkebunan, semak, tanah kosong dan tegalan/ladang. Penutupan lahan di Kecamatan Merawang didominasi oleh Perkebunan seluas 10614.64 ha, Semak 4589.75 ha, Tanah Kosong 2504.63 ha, Tegalan/Ladang 2203.96 ha dengan persentase 92.55\% dari luas kecamatan serta memiliki peringkat paling tinggi pada kriteria spasial Kliskey (2000). Kondisi ini dapat dimanfaatkan untuk pengembangan kawasan wisata pasca tambang karena lahan bekas di sekitar galian tambang yang berupa tanah kosong/gundul dapat dimanfaatkan untuk berbagai macam aktivitas wisata.

\section{Aksesibilitas}

Aksesibilitas dimaksud dengan radius jarak jangkauan jalan terhadap kawasan yang akan dikembangkan dengan kriteria spasial Kliskey (2000), sehingga mendapatkan bobot dan peringkat untuk melakukan analisis overlay kesesuaian wisata. Hampir semua jarak pada kawasan yang akan dikembangkan dalam hal ini merupakan kawasan wisata terletak pada jarak 0 sampai dengan $5 \mathrm{~km}$, yang artinya pada kriteria spasial Kliskey (2000) merujuk pada peringkat tertinggi untuk dikembangkan.

\section{Kemiringan}

Kemiringan di Kecamatan Merawang terletak pada 0 sampai dengan 30 derajat. Dalam kriteria spasial Kliskey (2000), satuan yang digunakan yaitu satuan derajat $\left(^{\circ}\right)$. Kecamatan Merawang didominasi oleh kemiringan 0 hingga 20 derajat dengan persentase $99.92 \%$ dari luas total keseluruhan kecamatan yaitu 21498.87 ha. Kondisi ini dapat menjadi potensi untuk dikembangkan kegiatan pariwisata karena didominasi oleh kemiringan lereng yang datar. Sementara untuk sisanya yaitu berada pada kemiringan 20 hingga 25 derajat dengan luas 11.17 ha atau $0.05 \%$ dari luas wilayah dan 25 sampai dnegan 30 ha dengan luas 5.98 ha atau $0.03 \%$ dari luas wilayah kecamatan.

\section{Vegetasi}

Berdasarkan kriteria spasial Kliskey kondisi vegetasi di Kecamatan Merawang meliputi pohon dan semak, serta lainnya yang merupakan pemanfaatan lahan diluar vegetasi. Kondisi vegetasi di Kecamatan Merawang didominasi oleh pohon yang dimana meliputi perkebunan dan hutan rimba. Adapun luas dari vegetasi pohon yaitu 10784.77 ha dengan persentase 50.12\% dari luas kecamatan. Sementara itu untuk semak memiliki luas 4589.75 ha atau $21.33 \%$ dari luas wilayah kecamatan serta untuk luasan lainnya yang berada diluar vegetasi meliputi permukiman, badan air dan lain-lain memiliki luas 6141.52 ha atau $28.54 \%$ dari luas wilayah.

\section{Topografi}

Kondisi topografi di Kecamatan Merawang memiliki ketinggian rendah dari 0 sampai 175 mdpl (meter diatas permukaan laut). Kondisi ini dapat menjadi potensi untuk dikembangkan berbagai macam aktivitas karena memiliki ketinggian yang relatif rendah. Topografi di Kecamatan Merawang didominasi oleh topografi rendah yaitu 0-25 mdpl dengan luas 16445.70 ha atau $76.43 \%$ dari luas kecamatan dan $25-50$ mdpl dengan luas 4868.11 ha atau $22.63 \%$ dari luas kecamatan. Untuk topografi 50-75 mdpl memiliki luas 162.65 ha atau $0.76 \%$ dari luas wilayah. Sementara itu untuk topografi 75-100 mdpl memiliki luas 19 ha atau $0.09 \%$ dari luas wilayah. Untuk topografi $100-125 \mathrm{mdpl}, 125-150 \mathrm{mdpl}, 150-175 \mathrm{mdpl}$ memiliki persentase masing-masing $0.03 \%$ dari luas wilayah kecamatan. 


\section{Kawasan Hutan dan Sempadan}

Berdasarkan Keputusan Menteri Kehutanan Nomor SK. 798 Tahun 2012 Kawasan hutan di Kecamatan Merawang terdiri dari hutan lindung dan hutan produksi tetap. Namun, dalam pengembangan kawasan wisata ini harus memerhatikan kawasan konservasi atau kawasan hutan yang tidak dapat dilakukan pengembangan. Dalam hal ini hutan produksi tetap merupakan kawasan hutan yang dapat dikembangkan dengan berbagai aktivitas diantaranya kegiatan wisata atau penggunaan kawasan yang bersifat komersial. Sementara itu, untuk hutan lindung merupakan kawasan dengan pengembangan bersyarat sebagai kawasan komersial karena merupakan kawasan penyangga yang berfungsi untuk mengatur tata air, mencegah intrusi air laut, mengendalikan erosi, mencegah banjir dan memelihara kesuburan tanah. Hutan lindung di Kecamatan Merawang memiliki luas 592.62 ha yaitu Hutan Lindung Bukit Rebo, sementara hutan produksi di Kecanatan Merawang terdiri dari Hutan Produksi Bukit Betung Sambung Giri, Hutan Produksi Air Limau, Hutan Produksi Kayu Besi dan Hutan Produksi Batu Rusa dengan luas 2833.18 ha.

Kawasan perlindungan setempat di Kecamatan Merawang terdiri dari sempadan sungai, pantai, kawasan sekitar kolong dan mata air. Kawasan perlindungan setempat tersebut berfungsi untuk pengaman batas luar yang ditetapkan dalam mendirikan kawasan terbangun sehingga fungsinya tidak terganggu oleh kegiatan disekitarnya. Berdasarkan Peraturan Menteri Pekerjaan Umum dan Perumahan Rakyat Republik Indonesia Nomor 28 Tahun 2015 menyatakan bahwa garis sempadan sungai paling sedikit $100 \mathrm{~m}$ di bagian kiri dan kanan sungai dan untuk sempadan pantai berdasarkan Peraturan Presiden Republik Indonesia Nomor 51 Tahun 2016 Tentang Batas Sempadan Pantai yaitu minimal $100 \mathrm{~m}$ dari titik pasang tertinggi kearah daratan. Sementara itu berdasarkan Peraturan Bupati Bangka Nomor 21 Tahun 2015 untuk kawasan sekitar kolong dan mata air yaitu minimal $50 \mathrm{~m}$ dari tepi kolong dan mata air ke arah darat. Berdasarkan perhitungan SIG Kecamatan Merawang memiliki luas sempadan pantai sebesar 155.79 ha, sempadan sungai sebesar 724.29 ha, kawasan sekitar kolong sebesar 632.96 ha dan kawasan sekitar mata air sebesar 105.62 ha.

\section{Kearifan Lokal di Kecamatan Merawang}

Kearifan lokal merupakan produk kebudayaan yang ada pada suatu daerah meliputi nilai, norma dan aturan yang menjadi acuan dalam melakukan suatu tindakan. Menurut Siagian et al. (2018) wisata budaya terus berkembang di berbagai daerah dan menjadi salah satu potensi dalam pengembangan pariwisata berbasis masyarakat lokal. Kearifan lokal pada suatu wilayah jika dikembangkan dalam industri pariwisata dapat meningkatkan perekonomian masyarakat sekitar dan dapat memperkenalkan budaya mereka kepada wisatawan. Menurut Vitasurya (2016) praktik kearifan lokal merupakan upaya masyarakat untuk melestarikan sumber daya yang dapat digunakan untuk memberi makan masyarakat itu sendiri dan menjaga keseimbangan lingkungan.

Sementara itu menurut Hamzah dan Irfan (2018) dalam jurnalnya menyebutkan bahwa pada aspek ekologi pemanfaatan sumber daya lingkungan secara optimal merupakan kunci dalam pengembangan pariwisata berbasis kearifan lokal dengan mempertahankan dan melestarikan keanekaragaman hayati daerah tujuan wisata, pada aspek ekonomi dapat memberikan manfaat jangka panjang seperti melihat peluang yang menghasilkan pendapatan bagi masyarakat lokal dan mengurangi kemiskinan, pada aspek sosial budaya yaitu dengan pelestarian nilai warisan budaya dan adat istiadat serta berkontribusi pada peningkatan toleransi dan pemahaman antar budaya. Berdasarkan beberapa sumber diantaranya tokoh masyarakat, dinas kebudayaan dan studi literatur, Kecamatan Merawang memiliki beberapa kearifan lokal yang menarik untuk dibahas diantaranya hutan adat, mitos perairan, taber, rebo kasan, malam-malam likur, nganggung, besaoh, kerajinan tangan khas, kuliner khas, mandik belimau dan becampak. 


\section{Hutan Adat}

Hutan adat merupakan hutan yang dilindungi oleh aturan adat. Menurut Cholillah (2017), secara tradisional, hutan atau rimba di pulau Bangka dibagi menjadi 4 jenis, yaitu Rimbek (hutan belantara yang masih alami dan lebat), Hutan Lareng (hutan yang didalamnya berlaku peraturan adat pantang larang dalam pengolahan hutan dan sistem penebangan pohon dan kayu), Hutan Haminte/Hutan Cadangan (hamparan hutan yang dimiliki oleh suatu kampung atau gabungan dari beberapa kampung), Kelekak (hutan bekas pemukiman lama yang telah lama ditinggalkan dan berubah menjadi hutan tanaman berbuah. Kelekak dapat dijumpai pada hampir semua wilayah di Kepulauan Bangka Belitung). Masyarakat Bangka percaya bahwa berbagai tempat di Pulau Bangka dijaga dan diatur oleh "penunggunya" yaitu roh dan makhluk halus. Dalam konteks sekarang seharusnya kepala-kepala rakyat di Bangka dapat kembali berperan dalam menjaga hutan atau rimba, lahan, tanah dan air sesuai dengan fungsi dan kemanfaatannya serta menjaga kelestarian lingkungan untuk kepentingan sekarang dan masa yang akan datang.

\section{Mitos Perairan}

Mitos perairan di Bangka yaitu agar tidak sembarangan menggunakan dan harus meminta izin kepada "penunggu" untuk mengelola tempat tersebut. Menurut Saxono (2019), buyut merupakan hantu air yang sering menenggelamkan orang di sungai, kolong dan pantai. Hantu air ini disebut seperti pusaran air. Seperti yang diketahui di dalam sungai atau kolong terdapat palung atau bekas galian yang membuat kita terperosok ke dalamnya. Kepercayaan ini sangat melekat di masyarakat Bangka khususnya di Kecamatan Merawang yang memiliki banyak galian atau kolong bekas pertambangan timah.

\section{Taber}

Menurut Elvian (2015), taber merupakan ritual tolak bala yang terdiri dari 4 macam yaitu taber darat, taber hutan, taber laut, sungai, dan taber kampung. Ritual ini juga berfungsi untuk melindungi dan menolak pengaruh roh jahat yang mengganggu manusia dan lingkungannya. Ritual taber dipimpin oleh dukun atau pawang dengan membaca mantra atau jampi terlebih dahulu dan membakar kemenyan sebelum memulai aksinya. Dalam ritual adat ini terdapat sesajian (sesajen) yang disajikan kepada makhluk halus terdiri dari pisang rejang, telur rebus dan nasi ketan. Setelah dilaksanakannya ritual adat tersebut dukun atau pawang menyampaikan pantangan yang tidak boleh dilakukan selama tiga hari seperti pergi melaut, bertengkar, menjuntai kaki diatas sampan sampai menyentuh air laut, menjemur pakaian di pagar, mencuci kelambu serta mencuci cincin di sungai atau di laut.

\section{Rebo Kasan}

Dalam buku Setiati (2009), Rebo Kasan merupakan upacara adat yang dilaksanakan setiap tahun di Desa Air Anyir, Kecamatan Merawang. Upacara merupakan ritual tolak bala atau tolak kesialan serta harapan nelayan agar hasil tangkapannya melimpah yang disimbolkan dengan ketupat lepas dan air wafa' serta dilaksanakan secara turun temurun oleh penduduk sekitar. Upacara Adat Rebo Kasan merupakan akulturasi dari mitos dan nilai-nilai religius serta legenda nenek moyang. Masyarakat percaya bahwa pada hari Rabu di akhir bulan Shafar, Tuhan menurunkan bencana dari terbit fajar sampai matahari terbenam sebanyak 320000 bencana baik besar maupun kecil. Kepercayaan tersebut menganjurkan untuk melakukan doa bersama sekaligus dengan pencabutan ketupat lepas sebagai tanda telah dicabutnya bencana. Ritual adat ini memiliki keunikan yaitu semu peserta yang ikut dalam ritual ini menggunakan jubah putih dan tambahan surban untuk tokoh agama islam. Sementara itu, untuk aparat pemerintah menggunakan seragam dinas. Dalam penyelenggaraan upacara Rebo Kasan nilai positif yang dapat diambil yaitu nilai kegotongroyongan, nilai kebersamaan dan nilai religius. Keunikan upacara Rebo Kasan ini dapat dapat dijadikan sebagai kegiatan untuk mengangkat pariwisata di Kabupaten Bangka khususnya di Kecamatan Merawang. 


\section{Malam-Malam Likur atau Selikur}

Menurut Saxono (2019), malam-malam likur merupakan adat masyarakat Bangka Belitung yang ditandai dengan memasang lampu/obor dari bambu yang diberi sumbu dan minyak tanah. Lampu/obor ini dipasang didepan rumah pada 10 malam terakhir bulan puasa. 1 likur, 3 likur, 5 likur, 7 likur dan berakhir pada malam 9 likur. Lampu obor tersebut dinamakan lampu likur. Pada setiap perbatasan antara desa dibangun gapura yang dihiasi pelita dan ukiran-ukiran kaligrafi Islami. Gapura tersebut memiliki bentuk seperti miniatur bangunan dan seni bernuansa Islami. Selain keindahan yang terlihat, masyarakat sangat semangat bergotong royong dalam proses pembuatan gapura yang titik apinya terbuat dari lampu sentir tradisional yang terbuat dari botol bekas minuman, sumbu kompor dan minyak tanah.

\section{Nganggung}

Menurut Suparta (2017), nganggung adalah salah satu budaya warisan leluhur Bangka Belitung yang paling berharga. Menurut Saxono (2019), nganggung melambangkan sifat dan sikap kegotongroyongan masyarakat serta merupakan identitas Bangka yang sesuai dengan slogan Sepintu Sedulang. Dalam acara ini, setiap kepala keluarga membawa dulang yaitu sejenis nampan bulat sebesar tampah yang terbuat dari aluminium atau kuningan dengan berbagai jenis makanan yang akan dibawa atas kesepakatan bersama. Dulang ini ditutup dengan tudung saji yang dibuat dari daun sejenis pandan dan dicat untuk dibawa ke masjid, surau atau tempat berkumpulnya warga kampung. Kegiatan ini juga sering dilakukan masyarakat dalam memperingati hari besar agama Islam, acara selamatan orang meninggal, menyambut tamu kehormatan dan acara pernikahan ataupun acara yang melibatkan orang banyak.

\section{Besaoh}

Dalam buku Saxono (2019), besaoh merupakan adat kebiasaan gotong royong secara bergantian, ketika mau membuka kebun baru, menebas hutan, mencari junjung sahang, membuat rumah dan lain-lain. Kegiatan ini dilaksanakan secara berkelompok dengan ikhlas/sukarela dan tanpa mengharapkan imbalan. Tujuan diadakannya kegiatan dalam masyarakat ini yaitu memupuk rasa solidaritas, kekompakan, saling membantu dan saling bahu-membahu ketika mempunyai pekerjaan/hajatan agar pekerjaan berjalan lancar dan waktu pelaksanaan sesuai dengan kesepakatan dari masing-masing kelompok.

\section{Kerajinan Tangan Khas}

Kerajinan tangan khas adalah karya seni dengan menggunakan keterampilan tangan yang biasa disebut dengan seni kriya. Pembuatan kerajinan tangan ini menggunakan bahan tertentu sehingga dapat dijadikan cenderamata bagi wisatawan dari luar daerah yang datang berkunjung ke Bangka. Menurut Saxono (2019), sesuatu yang dianggap khas dari Bangka, diantaranya akar bahar (dari dasar laut), pewter (terbuat dari timah), batu satam, tenunan kain cual, kerajinan kulit kerang-kerangan, anyam-anyaman (sungkok resam, suyak, sauki, tiker purun, kruntung, trindaq, tudung dulang, sumpit beduri, bubu).

\section{Kuliner Khas}

Kuliner khas merupakan hasil masakan dengan resep tertentu yang berasal dari Bangka Belitung. Pulau Bangka terkenal dengan masakan laut dan masakan khasnya. Dalam buku Saxono (2019), menyebutkan bahwa kuliner khas ini terdiri dari beberapa macam diantaranya makanan berat, makanan ringan dan camilan. Makanan berat tersebut seperti lempah darat, lempah kuning, mangoet, gembung betelok, bekasem, sambelingkung, rusep, ikan kukus, tenges dan lain-lain. Makanan ringan atau biasa disebut selingan yang mirip bahkan sama dengan yang ada di daerah lain yaitu mie kuak ikan, mi bangka (mian), tek wan, bak wan, laksha/lakso, pan tiauw, rujak su'un, urap, ketupat, lontong, sate, burgo dan lain-lain. Adapun kuliner khas Bangka berupa camilan yang terbagi menjadi dua kelompok yaitu camilan jenis basah dan camilan kering, 
camilan jenis basah berupa Rangai, yetiyet, lumpang, sengkulon, tumpik silung, panekuq, lepet, jemput, kiping, kelamai, kue masin/gandus, srabi dan lain-lain. Sementara itu, untuk jenis kering berupa kretek/getes, kemplang, siputgunggung, sutong kering, rintak, kritcu dan lain-lain. Adapun kuliner khas Bangka yang sangat terkenal di luar daerah yaitu martabak atau biasa disebut hok lo phan atau panekuq dan mian (mie Bangka), belacan, kreteq/getes, kritcu dan sambelingkung serta siput gunggung.

\section{Mandik Belimau}

Menurut Herdiyanti dan Cholillah (2017), mandik belimau merupakan ritual mandi bersih seminggu sebelum datangnya bulan Ramadhan yang dilaksanakan di Desa Jada Bahrin dan Desa Kimak. Upacara adat ini telah dilakukan selama kurang lebih 300 tahun silam yang kemudian dicetuskan oleh Depati Bahrin. Menurut Saxono (2019), para tamu disiram dengan air wafa' yang telah dicampur dengan abu kertas bertulisan Arab yang sudah dibakar, campuran limau atau 7 macam jeruk yang telah direndam dalam air tersebut. Keharuman bahan campuran limau tersebut baik untuk penyambutan bulan Ramadhan dan pembersihan diri. Tradisi mandik belimau ini merupakan tradisi ziarah ke makam tokoh masyarakat atau pahlawan kemudian pergi ke tempat acara mandi belimau.

\section{Becampak atau Tari campak}

Menurut Saxono (2019), becampak merupakan kebiasaan menghibur diri dan orang lain dengan berbalas pantun yang dinyanyikan sambil menari. Tarian dalam adat istiadat becampak termasuk tarian yang populer dan ikonis di Kepulauan Bangka Belitung tepatnya di Belitung. Namun seiring berkembangnya waktu, tarian ini populer hingga ke seluruh penjuru masyarakat Bangka Belitung. Tariannya menggambarkan ekspresi keceriaan bujang dan dayang di sana dengan diiringi musik khas Melayu yang mengiringi tarian terdiri dari piyul (biola), gong, gendang, dan keyboard atau akordion serta merupakan akulturasi budaya melayu dan portugis. Pada zaman dahulu, tarian campak biasanya dilakukan pada musim panen padi dan pulang berkebun. Seiring berkembangnya waktu, tarian ini digunakan sebagai hiburan dalam berbagai kegiatan seperti acara pesta rakyat, penyambutan tamu kehormatan dan acara adat pernikahan.

\section{Kesesuaian Wisata Kawasan Pasca Tambang}

Kesesuaian wisata pasca tambang diperoleh dengan cara melihat kondisi fisik dan biofisik untuk keberlanjutan suatu lanskap tersebut. Hasil dari analisis kesesuaian wisata digunakan untuk menggambarkan tingkat kesesuaian untuk penggunaan aktivitas pada kawasan pasca tambang karena pada dasarnya pengembangan kawasan wisata dapat menimbulkan dampak pada kondisi fisik dan biofisik apabila tidak diperhitungkan dengan baik. Perencanaan untuk pengembangan wisata perlu dilakukan untuk menilai kepekaan suatu lanskap, sehingga dapat melakukan zonasi kawasan serta peruntukan yang sesuai dengan kemampuan kawasan. Analisis kesesuaian wisata dilakukan dengan menggunakan kriteria spasial Kliskey (2000) dengan beberapa faktor terkait yaitu keterbukaan (penutupan lahan), aksesibilitas, kemiringan, vegetasi, dan topografi. Hasil dari analisis ini dioverlay kembali menggunakan SIG dengan data kawasan hutan dan sempadan sehingga menghasilkan peta kesesuaian kawasan wisata dengan tetap memerhatikan kawasan existing yang telah ditetapkan oleh kebijakan pemerintah.

Hasil dari analisis ini menunjukkan bahwa kesesuaian wisata di Kecamatan Merawang memiliki tiga kesesuaian untuk pengembangan kawasan wisata. Kecamatan Merawang didominasi oleh kesesuaian wisata tinggi atau sangat sesuai (S1) dengan nilai indeks kesesuaian wisata (IKW) sebesar 84.05\% atau 18084.49 ha dari luas wilayah. Untuk kesesuaian wisata rendah atau sesuai bersyarat (S3) memiliki nilai indeks kesesuaian wisata (IKW) sebesar $9.31 \%$ atau 2002.11 ha dari luas wilayah. Sementara itu, untuk kesesuaian wisata nol atau tidak sesuai $(\mathrm{N})$ memiliki nilai indeks kesesuain wisata sebesar $6.66 \%$ atau 1432.93 ha dari luas wilayah. Berdasarkan analisis kesesuaian wisata sebagian besar kondisi fisik dan biofisik di Kecamatan Merawang dapat dikembangkan menjadi tujuan wisata karena hampir semua luas kawasannya memiliki nilai kesesuaian 
yang sangat sesuai. Menurut Gultom et al. (2018), nilai kesesuaian wisata yang sangat sesuai digabungkan dengan nilai kesesuaian sedang atau sesuai dapat dilakukan pengembangan untuk aktivitas wisata. Sementara itu, untuk kesesuain wisata nol atau tidak sesuai letak dan posisinya tidak menjadi kendala bagi pengembangan kawasan bahkan secara tidak langsung dapat mendukung kawasan pengembangan. Hal ini diperkuat juga oleh penelitian sebelumnya yang dilakukan Meyana et al. (2015) bahwa jenis pengembangan wisata pada area pasca tambang timah adalah jenis wisata alam yang diikuti dengan wisata budaya dan selanjutnya jenis wisata buatan sebagai pendukung kegiatan wisata. Untuk lebih jelasnya, sebaran kesesuaian wisata pada kawasan pasca tambang di Kecamatan Merawang dapat dilihat pada Tabel 3 dan Gambar 2 dibawah ini.

Tabel 3 Indeks kesesuaian wisata di Kecamatan Merawang

\begin{tabular}{clcc}
\hline No & \multicolumn{1}{c}{ Indeks Kesesuaian Wisata (IKW) } & Luas (ha) & Persentase (\%) \\
\hline 1 & Nol/Tidak Sesuai (N) & 1432.93 & 6.66 \\
2 & Rendah/Sesuai Bersyarat (S3) & 2002.11 & 9.31 \\
3 & Tinggi/Sangat Sesuai (S1) & 18084.49 & 84.05 \\
\hline \multicolumn{2}{r}{ Jumlah } & 21516.03 & 100 \\
\hline
\end{tabular}

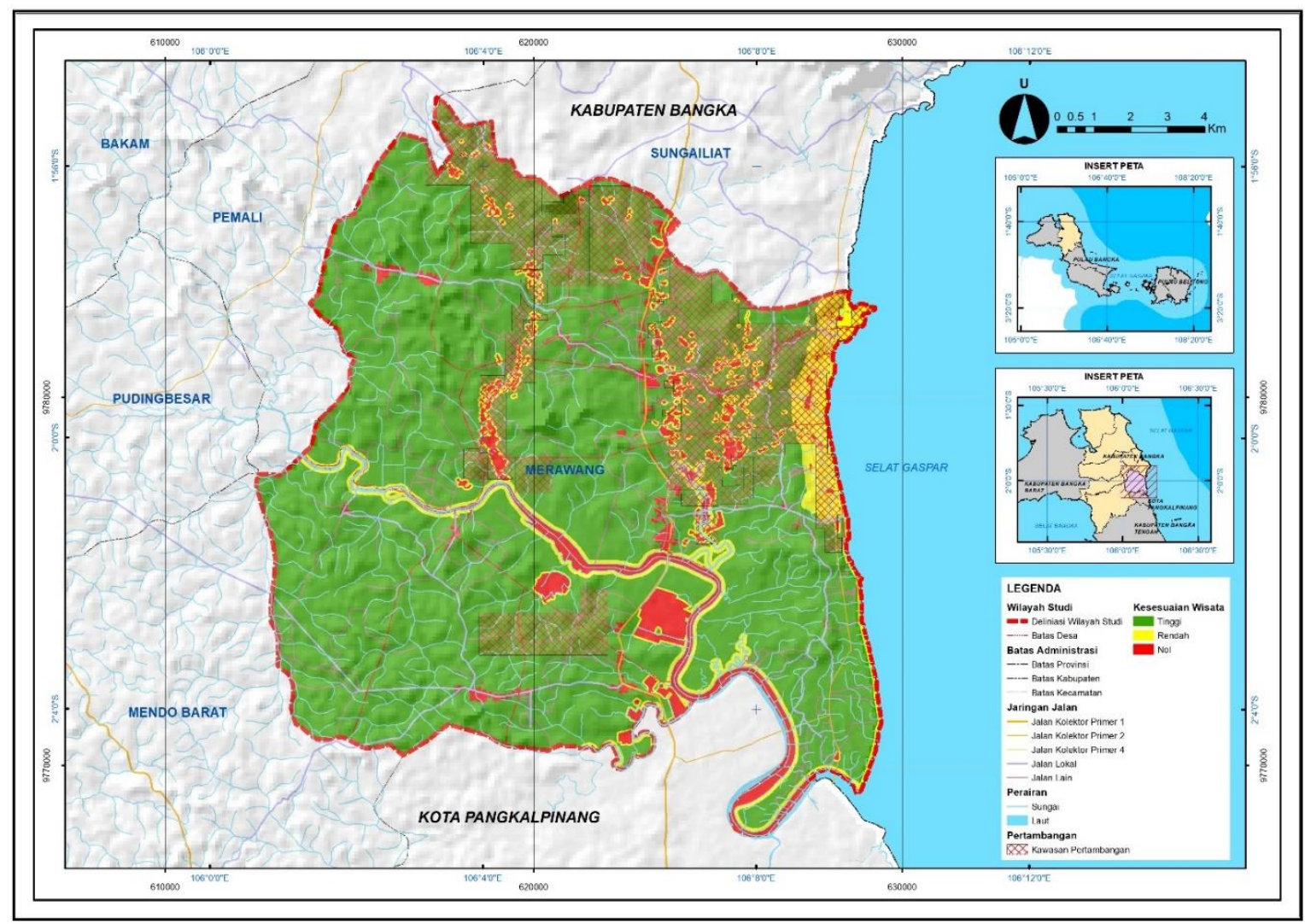

Gambar 2 Sebaran indeks kesesuaian wisata (IKW)

\section{Aspek Prioritas Pengembangan}

Kearifan lokal merupakan produk kebudayaan yang ada pada suatu daerah meliputi nilai, norma dan aturan yang menjadi acuan dalam melakukan suatu tindakan. Kecamatan Merawang memiliki beberapa kearifan lokal yang menarik untuk dibahas diantaranya hutan adat, mitos perairan, taber, rebo kasan, malammalam likur, nganggung, besaoh, kerajinan tangan khas, kuliner khas, mandik belimau dan becampak. Analisis aspek prioritas pada penelitian ini difokuskan pada empat variabel aspek yaitu aspek ekologi, sosial, ekonomi dan sejarah. Pada penilaian ini variabel aspek yang paling penting untuk dikembangkan dari penilaian para responden yaitu aspek ekonomi. Aspek ekonomi paling penting untuk dikembangkan karena menurut pendapat 384 
para responden aspek ekonomi dapat meningkatkan nilai pendapatan untuk masyarakat sekitar dengan adanya partisipasi masyarakat dalam kegiatan wisata seperti menyediakan jasa, menjual suvenir, membuka restoran atau tempat makan, membuat home stay, dan lain-lain. Hal ini diperkuat oleh penelitian sebelumnya yang dilakukan Siagian et al. (2018), dalam jurnalnya menyebutkan bahwa pengembangan wisata budaya bertujuan untuk memperkenalkan budaya mereka kepada dunia yang menjadi identitas mereka, melestarikan budaya dan meningkatkan ekonomi masyarakat lokal. Untuk lebih jelasnya dapat dilihat pada Tabel 4 dibawah ini.

Tabel 4 Analisis aspek prioritas

\begin{tabular}{lccccc}
\hline \multirow{2}{*}{ Responden Ahli } & \multicolumn{4}{c}{ Faktor Penting } & IR \\
\cline { 2 - 5 } & Aspek Ekologi & Aspek Sosial & Aspek Ekonomi & Aspek Sejarah & (Inconsistensy Ratio) \\
\hline Dinas Pariwisata & 0.133 & 0.264 & 0.461 & 0.141 & 0.07 \\
Dinas Kebudayaan & 0.251 & 0.157 & 0.488 & 0.103 & 0.05 \\
Tokoh Masyarakat & 0.077 & 0.168 & 0.517 & 0.238 & 0.04 \\
\hline
\end{tabular}

\section{Kearifan Lokal Prioritas Berdasarkan Aspek}

Kearifan lokal prioritas berdasarkan semua aspek diperoleh dari nilai kombinasi semua responden para ahli terhadap aspek yang dimaksud. Pada aspek ekologi variabel kearifan lokal yang diperoleh yaitu "hutan adat" dengan nilai 0.185 dan IR sebesar 0.03 . Kearifan lokal prioritas pada aspek ekologi berhubungan dengan ketersediaan sumber daya dan konservasi lingkungan dalam perencanaan kawasan wisata yang digunakan dalam kearifan lokal yang dimaksud. Menurut responden para ahli variabel "hutan adat" dinilai sangat penting dalam aspek ekologis karena seharusnya masyarakat dan kepala daerah di Bangka dapat kembali berperan dalam menjaga hutan atau rimba, lahan, tanah dan air sesuai dengan fungsi dan kemanfaatannya serta menjaga kelestarian lingkungan untuk kepentingan sekarang dan masa yang akan datang khususnya pada kawasan pasca tambang timah. Pada aspek sosial variabel yang paling penting untuk dikembangkan yaitu variabel "nganggung" dengan nilai 0.252 dan IR sebesar 0.04. Aspek sosial berhubungan dengan besarnya jumlah tenaga kerja yang mampu diserap dari melakukan kearifan lokal yang dimaksud dalam pengembangan wisata, serta prospek keberlanjutan dari usaha tersebut. Ritual "nganggung” sesuai dengan slogan Sepintu Sedulang yang ada di Bangka dengan mencerminkan sikap kegotongroyongan dengan membawa makanan di dalam dulang yang ditutup dengan "tudung saji" ke masjid atau tempat berkumpulnya warga kampung. Ritual ini dapat menjadi daya tarik wisata dengan melibatkan masyarakat sekitar. Kearifan lokal prioritas pada aspek ekonomi berhubungan dengan besarnya nilai pendapatan yang diterima oleh masyarakat yang melakukan kearifan lokal yang dimaksud dalam pengembangan wisata, serta cakupan pasarnya. Pada aspek ekonomi variabel yang paling penting untuk dikembangkan yaitu variabel "kuliner khas" dengan nilai 0.271 dan IR sebesar 0.04. Variabel "kuliner khas" paling penting dikembangkan pada aspek ekonomi karena kuliner khas dari Bangka beraneka ragam diantaranya terdapat makanan berat yang dapat disajikan di rumah makan atau restoran, makanan ringan sebagai camilan di tempat wisata serta snack yang dapat dijadikan oleh-oleh untuk wisatawan yang datang ke tempat wisata. Dari variabel ini dapat menghasilkan pendapatan terhadap masyarakat sekitar dan dapat memperkenalkan kuliner khas kepada wisatawan yang datang.

Pada aspek sejarah variabel yang paling penting untuk dikembangkan yaitu variabel atau kearifan lokal "becampak" dengan nilai 0.236 dan IR sebesar 0.03. Kearifan lokal prioritas pada aspek sejarah berhubungan dengan sejarah adanya kearifan lokal pada lanskap tropis di Kecamatan Merawang. Menurut para ahli, variabel "becampak" jika dilihat dari sisi sejarah Tari Campak ini merupakan akulturasi budaya Melayu dengan budaya Portugis karena dahulu Bangka Belitung sempat berada di bawah penjajahan Portugis. Akulturasi kedua budaya terlihat pada alat musik pengiringnya berupa akordion dan biola dari Eropa yang didampingi gong dan gendang sebagai budaya lokal asli khas Melayu. Tarian ini dapat dikembangkan sebagai hiburan pada berbagai kegiatan dalam hal ini pada pengembangan kawasan wisata. Untuk lebih jelasnya dapat dilihat pada Tabel 5 dibawah ini. 
Tabel 5 Kearifan lokal prioritas berdasarkan aspek

\begin{tabular}{|c|c|c|c|c|c|}
\hline Aspek & Nilai & Kearifan Lokal & Nilai & IR (Inconsistensy Ratio) & Prioritas \\
\hline \multirow{11}{*}{ Ekologi } & \multirow{11}{*}{0.144} & Hutan Adat & 0.185 & \multirow{11}{*}{0.03} & 1 \\
\hline & & Mitos Perairan & 0.135 & & 4 \\
\hline & & Taber & 0.151 & & 3 \\
\hline & & Rebo Kasan & 0.153 & & 2 \\
\hline & & Malam-malam likur & 0.085 & & 5 \\
\hline & & Nganggung & 0.049 & & 7 \\
\hline & & Besaoh & 0.075 & & 6 \\
\hline & & Kuliner khas & 0.035 & & 11 \\
\hline & & Kerajinan tangan khas & 0.045 & & 8 \\
\hline & & Mandik Belimau & 0.045 & & 9 \\
\hline & & Becampak & 0.042 & & 10 \\
\hline \multirow{11}{*}{ Sosial } & \multirow{11}{*}{0.198} & Hutan Adat & 0.054 & \multirow{11}{*}{0.04} & 8 \\
\hline & & Mitos Perairan & 0.029 & & 11 \\
\hline & & Taber & 0.083 & & 5 \\
\hline & & Rebo Kasan & 0.069 & & 6 \\
\hline & & Malam-malam likur & 0.144 & & 3 \\
\hline & & Nganggung & 0.252 & & 1 \\
\hline & & Besaoh & 0.158 & & 2 \\
\hline & & Kuliner khas & 0.033 & & 10 \\
\hline & & Kerajinan tangan khas & 0.039 & & 9 \\
\hline & & Mandik Belimau & 0.069 & & 7 \\
\hline & & Becampak & 0.101 & & 4 \\
\hline \multirow{11}{*}{ Ekonomi } & \multirow{11}{*}{0.501} & Hutan Adat & 0.03 & \multirow{11}{*}{0.04} & 11 \\
\hline & & Mitos Perairan & 0.022 & & 10 \\
\hline & & Taber & 0.041 & & 9 \\
\hline & & Rebo Kasan & 0.043 & & 8 \\
\hline & & Malam-malam likur & 0.071 & & 6 \\
\hline & & Nganggung & 0.086 & & 4 \\
\hline & & Besaoh & 0.045 & & 7 \\
\hline & & Kuliner khas & 0.271 & & 1 \\
\hline & & Kerajinan tangan khas & 0.2 & & 2 \\
\hline & & Mandik Belimau & 0.073 & & 5 \\
\hline & & Becampak & 0.117 & & 3 \\
\hline \multirow{11}{*}{ Sejarah } & \multirow{11}{*}{0.156} & Hutan Adat & 0.099 & \multirow{11}{*}{0.03} & 4 \\
\hline & & Mitos Perairan & 0.03 & & 11 \\
\hline & & Taber & 0.039 & & 10 \\
\hline & & Rebo Kasan & 0.054 & & 7 \\
\hline & & Malam-malam likur & 0.044 & & 8 \\
\hline & & Nganggung & 0.066 & & 5 \\
\hline & & Besaoh & 0.041 & & 9 \\
\hline & & Kuliner khas & 0.063 & & 6 \\
\hline & & Kerajinan tangan khas & 0.121 & & 3 \\
\hline & & Mandik Belimau & 0.207 & & 2 \\
\hline & & Becampak & 0.236 & & 1 \\
\hline
\end{tabular}




\section{Analisis Kearifan Lokal Prioritas Secara Keseluruhan}

Kearifan lokal prioritas secara keseluruhan diperoleh berdasarkan nilai kombinasi semua aspek. Dalam penilaian tersebut, variabel kearifan lokal yang paling prioritas dikembangkan yaitu "kuliner khas" dengan nilai 0.157 . Setelah mendapatkan penilaian kearifan lokal pada kombinasi semua aspek, penilaian kembali dilakukan dengan membandingkan penilaian kombinasi menurut para ahli berdasarkan urutan nilai variabel kombinasi semua aspek. Berdasarkan penilaian masing-masing responden diperoleh nilai variabel tertinggi dengan variabel kearifan lokal "kuliner khas" dengan nilai 0.465 . Hasil ini sesuai dengan hasil yang didapat pada penilaian sebelumnya. Untuk lebih jelasnya dapat dilihat pada Tabel 6.

Tabel 6 Nilai kearifan lokal prioritas secara keseluruhan

\begin{tabular}{lcccccc}
\hline \multirow{2}{*}{$\begin{array}{c}\text { Kearifan lokal prioritas } \\
\text { semua aspek }\end{array}$} & Nilai & Prioritas & $\begin{array}{c}\text { Dinas } \\
\text { Pariwisata }\end{array}$ & $\begin{array}{c}\text { Dinas } \\
\text { Kebudayaan }\end{array}$ & $\begin{array}{c}\text { Tokoh } \\
\text { Masyarakat }\end{array}$ & Jumlah \\
\hline Kuliner khas & 0.157 & 1 & 0.156 & 0.142 & 0.158 & 0.465 \\
Kerajinan Tangan Khas & 0.133 & 2 & 0.132 & 0.129 & 0.132 & 0.393 \\
Becampak & 0.122 & 3 & 0.107 & 0.103 & 0.155 & 0.365 \\
Nganggung & 0.110 & 4 & 0.135 & 0.099 & 0.097 & 0.331 \\
Mandik belimau & 0.089 & 5 & 0.08 & 0.076 & 0.112 & 0.268 \\
Malam-malam likur & 0.077 & 6 & 0.077 & 0.102 & 0.065 & 0.244 \\
Besaoh & 0.071 & 7 & 0.077 & 0.065 & 0.068 & 0.21 \\
Hutan Adat & 0.068 & 8 & 0.061 & 0.08 & 0.067 & 0.208 \\
Rebo Kasan & 0.066 & 9 & 0.072 & 0.077 & 0.052 & 0.201 \\
Taber & 0.065 & 10 & 0.06 & 0.076 & 0.058 & 0.194 \\
Mitos perairan & 0.041 & 11 & 0.041 & 0.052 & 0.035 & 0.128 \\
\hline
\end{tabular}

\section{SIMPULAN}

Kawasan pasca tambang di Kecamatan Merawang dapat dilakukan pengembangan menjadi kawasan wisata berbasis kearifan lokal. Hal ini dibuktikan dengan hasil analisis spasial kesesuaian wisata yang menunjukkan sebagian besar wilayah Kecamatan Merawang memiliki kriteria yang sangat sesuai (S1) dengan nilai indeks kesesuaian wisata (IKW) sebesar $84.05 \%$ atau 18084.49 ha dari luas wilayah dan sesuai bersyarat (S3) dengan nilai indeks kesesuaian wisata (IKW) sebesar 9.31\% atau 2002.11 ha dari luas wilayah. Sementara itu, untuk kesesuaian wisata nol atau tidak sesuai (N) memiliki nilai indeks kesesuain wisata sebesar 6.66\% atau 1432.93 ha dari luas wilayah.

Untuk pengembangan kearifan lokal di Kecamatan Merawang khususnya di sekitar area pasca tambang berdasarkan analisis AHP diperoleh pada aspek ekologi yaitu "hutan adat", aspek sosial yaitu "nganggung", aspek ekonomi yaitu "kuliner khas" dan aspek sejarah yaitu "becampak". Sementara itu kearifan lokal prioritas berdasarkan keseluruhan aspek diperoleh kearifan lokal "kuliner khas". Pada pengembangan kearifan lokal tidak menutup kemungkinan untuk mengembangkan semua variabel kearifan lokal yang saling terkait sehingga kelestarian budaya dapat dipertahankan dan memperkenalkan kepada wisatawan khususnya dari luar wilayah Kepulauan Bangka Belitung.

\section{DAFTAR PUSTAKA}

Anwar DR, Makalew AD, Pramukanto Q. 2012. Master Plan of Post Mining Area on ABGC Model. Proceeding of IFLA-Asia Region Conference.

Badan Informasi Geospasial. 2018. Peta Rupabumi Digital Indonesia [Internet]. Bogor (ID): Badan Informasi Geospasial. Tersedia pada: http://tanahair.indonesia.go.id/portal-web/. 
Chamidah N, Imawan K, Mudhofar. 2018. The concept of developing local wisdom-based tourism villages in Cirebon Regency, West Java, Indonesia: Integrated marketing communication perspective. Adv Soc Sci Educ Humanit Res. 136: 314-320.

Chasanah I, Purnomo PW, Haeruddin H. 2017. Analisis kesesuaian wisata pantai jodo Desa Sidorejo Kecamatan Gringsing Kabupaten Batang. Jurnal Pengelolaan Sumberdaya Alam dan Lingkungan. 7(3): 235-243.

Cholillah J. 2017. Pengelolaan hutan berbasis budaya lokal di Dusun Pejam Kabupaten Bangka. Jurnal Society. $5(1): 45-58$.

Elvian A. 2015. Memarung, Panggung, Bubung, Kampung dan Nganggung. Pangkalpinang (ID): Dinas Kebudayaan, Pariwisata, Pemuda dan Olahraga Kota Pangkalpinang.

Ghazali I, Setyobudiandi I, Kinseng RA. 2014. Community base of mangrove management in Surabaya east coast. Depik. 3(3): 195-206.

Gold SM. 1980. Recreation Planning and Design. New York (US): McGraw-Hill Book Co.

Gultom Togar LM, Makalew ADN, Nasrullah N. 2018. Perencanaan lanskap kaliurang sebagai kawasan wisata terpadu di Yogyakarta. J Lanskap Indones. 10(2): 57-70.

Hamzah AS, Irfan M. 2018. Local wisdom based tourist village sade lombok organization within the framework of sustainable tourism development. Adv Soc Sci Educ Humanit Res. 282: 129-132.

Herdiyanti H, Cholillah J. 2017. Pergeseran modal sosial dalam pelaksanaan upacara adat mandi belimau di Dusun Limbung Desa Jada Bahrin Kecamatan Merawang Kabupaten Bangka. Society. 5(2): 1-15.

Siagian DJM, Hamsari H, Zuska F. 2018. Local wisdom of batak toba in supporting tourism sector in Regency of Samosir. Adv Soc Sci Educ Humanit Res. 136: 210-215.

Kliskey AD. 2000. Recreation terrain suitability mapping: A spatially explicit methodology for determining recreation potential for resource use assessment. Landsc Urban Plan. 52(1): 33-43.

Meyana L, Sudadi U, Tjahjono B. 2015. Direction and strategy of former tin mining area development as tourism area In Bangka Regency. J Nat Resour Environ Manag. 5(1): 51-60.

Pemerintah Indonesia. 2012. Keputusan Menteri Kehutanan Nomor SK. 798 Tahun 2012 Tentang Perubahan Peruntukan Kawasan Hutan Menjadi Bukan Kawasan Hutan, Perubahan Fungsi Kawasan Hutan dan Penunjukan Bukan Kawasan Hutan Menjadi Kawasan Hutan di Provinsi Kepulauan Bangka Belitung, No. 2. Jakarta (ID): Kementrian Kehutanan Republik Indonesia.

Pemerintah Indonesia. 2015. Peraturan Menteri Pekerjaan Umum dan Perumahan Rakyat Republik Indonesia Nomor 28 Tahun 2015 Tentang Penetapan Garis Sempadan Sungai dan Garis Sempadan Danau, No. 20 Jakarta (ID): Kementrian Pekerjaan Umum dan Perumahan Rakyat.

Pemerintah Indonesia. 2016. Peraturan Presiden Republik Indonesia Nomor 51 Tahun 2016 Tentang Batas Sempadan Pantai, No. 18. Jakarta (ID): Sekretariat Kabinet Republik Indonesia.

Pemerintah Kabupaten Bangka. 2012. Peraturan Daerah Kabupaten Bangka Nomor 1 Tahun 2013 Tentang Rencana Tata Ruang Wilayah Kabupaten Bangka Tahun 2010-2030. Kabupaten Bangka (ID): Bupati Bangka.

Pemerintah Kabupaten Bangka. 2015. Salinan Peraturan Bupati Bangka Nomor 21 Tahun 2015 Tentang Kriteria Sempadan Kawasan Perlindungan Setempat di Kabupaten Bangka. Kabupaten Bangka (ID): Bupati Bangka.

Pemerintah Kabupaten Bangka. 2019. Kabupaten Bangka Dalam Angka Tahun 2019. Kabupaten Bangka (ID): Badan Pusat Statistik Kabupaten Bangka.

Pemerintah Kabupaten Bangka. 2019. Data Primer dan Sekunder. Kabupaten Bangka (ID): Dinas Pariwisata, Kepemudaan dan Olahraga Kabupaten Bangka.

Pemerintah Kabupaten Bangka. 2019. Data Primer dan Sekunder. Kabupaten Bangka (ID): Dinas Pendidikan dan Kebudayaan Kabupaten Bangka.

Pemerintah Kabupaten Bangka. 2019. Data Sekunder Peta Spasial. Kabupaten Bangka (ID): Dinas Pekerjaan Umum dan Perumahan Rakyat Kabupaten Bangka. 
PT. Timah Tbk. 2018. Penguatan Daya Saing Global Melalui Strategi Keberlanjutan. Laporan Keberlanjutan. Bangka Belitung (ID): PT. Timah Tbk.

Saaty TL. 1990. Decision Making for Leaders: the Analytic Hierarchy Process for Decisions in A Complex World. Pittsburgh (US): University of Pittsburgh.

Sangchumnong A. 2019. Development of a sustainable tourist destination based on the creative economy: A case study of klong kone mangrove community, Thailand. Kasetsart J Soc Sci. 40(3): 642-649.

Sari DP, Buchori I. 2015. Efektivitas program reklamasi pasca tambang timah Di Kecamatan Merawang Kabupaten Bangka. J Pembang Wil dan Kota. 11(3): 299-312.

Saxono W. 2019. Arsip Buku Muatan Lokal. Bangka (ID): Lembaga Kesenian Masyarakat dan Grup Musik Bujang Betuah Kabupaten Bangka.

Setiati D. 2009. Upacara Rebo Kasan Provinsi Kepulauan Bangka Belitung. Tanjungpinang (ID): Departemen Kebudayaan dan Pariwisata Balai Pelestarian Sejarah dan Nilai Tradisional Tanjungpinang.

Suparta S. 2017. Nilai-nilai pendidikan islam dalam budaya nganggung dan implikasinya terhadap solidaritas umat di Kecamatan Mendo Barat Kabupaten Bangka. Madania. 21(1): 101-112.

Syartinilia, Wahyuni S, Siahainenia AJ, Santoso I. 2019. Environmentally sensitive area models for supporting West Papua conservation province. Proc SPIE, Sixth Int Symp LAPAN-IPB Satel. 113721.

Vitasurya VR. 2016. Local wisdom for sustainable development of rural tourism, case on Kalibiru and Lopati Village, Province of Daerah Istimewa Yogyakarta. Procedia-Soc Behav Sci. 216:97-108. 